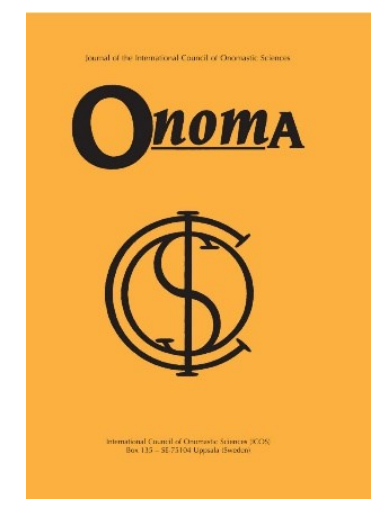

Onoma 54

Journal of the International Council of Onomastic

Sciences

ISSN: 0078-463X; e-ISSN: 1783-1644

Journal homepage: https://onomajournal.org/

\title{
Sociocultural inscriptions in a personal name: A case study of name-giving in Latvia
}

DOI: 10.34158/ONOMA.54/2019/10

\section{Anna Elizabete Griķe}

Latvian Language Institute, University of Latvia

Akademijas laukums 1-913

LV 1050, Riga

Latvia

annagrike88@gmail.com

To cite this article: Griķe, Anna Elizabete. 2019 Sociocultural inscriptions in a personal name: A case study of name-giving in Latvia. Onoma 54, 181196. DOI: $10.34158 /$ ONOMA.54/2019/10

To link to this article: https://doi.org/10.34158/ONOMA.54/2019/10

\section{(C) Onoma and the author.}

Sociocultural inscriptions in a personal name: A case study of name-giving in Latvia

Abstract: The study of name-giving practices is of particular interest not only because of the sociocultural inscriptions but also of a broader idea of on-going processes within a concrete society; names can serve as its barometer. The Central Statistical Bureau of Latvia has provided an overview of hundred most popular personal names in Latvia in the past hundred years. Merging data from this tool, indepths interviews and findings of Latvian onomasticians, I investigate the namegiving process in contemporary Latvia. What aspects does the name-giving involve and how does the personal experience influence it? In which sense one can talk about preferences, choices, traditions and transmissions? It is not the popularity or unpopularity of a name but a sense of certain freedom of choice that unites the name-givers in contemporary Latvia, their motivation always being an intersection of local social and cultural realms, such as the name day calendar.

Keywords: Anthroponomy, name-giving, name day calendar, Latvia. 


\section{Inscriptions socioculturelles dans un prénom : L'étude de cas de la prénomination en Lettonie}

Résumé : L'étude des pratiques de la prénomination est d'un intérêt particulier non seulement à cause des inscriptions socioculturelles mais aussi à cause d'une idée plus large des procès à jour dans une société donnée ; les prénoms peuvent servir en tant que son baromètre. Le Bureau Central de la Statistique de Lettonie a fourni un aperçu des cent prénoms les plus populaires des dernières cent années. En rejoignant les données dudit outil, des interviews et les conclusions des onomasticiens lettons, je recherche le procès de la prénomination en Lettonie contemporaine. Quels aspects ce procès inclut et comment l'expérience personnelle l'influence ? Dans quelle mesure peut-on parler des préférences, choix, traditions et transmissions ? Ce n'est pas la popularité ou l'impopularité d'un prénom mais un sentiment de liberté qui unit les donneurs des prénoms en Lettonie, leur motivation étant toujours l'intersection des realia sociales et culturelles, telle que le calendrier des prénoms.

Mots-clés : Anthroponymie, prénomination, calendrier des prénoms, Lettonie.

\section{Soziokulturelle Aspekte der Personennamen:}

Eine Fallstudie zur Namengebung in Lettland

Zusammenfassung: Das Studium der Namengebungspraktiken ist nicht nur wegen der soziokulturellen Aspekte der Vornamen von besonderem Interesse, sondern auch wegen einer breiteren Darstellung aktueller gesellschaftlicher Prozesse. Die Namen können als Barometer dienen. Das zentrale Amt für Statistik in Lettland hat ein Programm erarbeitet, das die hundert beliebtesten Personennamen in Lettland in den letzten hundert Jahren umfasst. Der vorliegende Beitrag analysiert die Namengebung im heutigen Lettland auf Grund der Daten aus diesem Programm, der vertieften Interviews und der Forschungen lettischer Onomasten. Welche Aspekte beinhaltet die Namengebung und wie wird sie von der persönlichen Erfahrung beeinflusst? In welchem Sinne kann man über Vorlieben, Entscheidungen, Traditionen und Überlieferungen sprechen? Es ist nicht die Popularität oder die Unbeliebtheit eines Namens, sondern ein Gefühl der Entscheidungsfreiheit, das die Namengeber im heutigen Lettland vereint. Die Motivation der Namengebung vereint in sich verschiedene lokale soziale und kulturelle Gegebenheiten, darunter z. B. auch den Vornamenkalender.

Schlüsselbegriffe: Anthroponymie, Namengebung, Vornamenkalender, Lettland. 


\title{
Sociocultural inscriptions in a personal name: A case-study of name giving in Latvia
}

\author{
ANNA EliZABETE GRIK̦E
}

\section{Introduction}

In 2018, Latvia was celebrating its centenary since the declaration of independence. Next to other numerous commemorative events and actions, the Central Statistical Bureau of Latvia (2018) presented as a gift an overview of the hundred most popular personal names in Latvia in the past hundred years by classifying them by gender and region. This tool allows us to see how the popularity of given names changes in time and in different areas. While exploring different scientific articles about name giving in Latvia, I used this tool to follow up some of the observations.

Researching Latvian naming patterns between years 1880 and 1991, Laimute Balode \& Edwin Lawson (1996: 248) state that during the Latvian Soviet period "there were few ways that patriotic Latvians could affirm and show their ethnic identity. One of these was to choose names for their children that would demonstrate patriotism." Three years later, Ojārs Bušs (1999), in his article about the latest tendencies within the name giving patterns, follows the thought by observing a downshift of personal names of Latvian origin. By putting ten male personal names that Bušs identifies as of Latvian origin in the previously mentioned tool, we obtain the following statistics for the whole of Latvia.

As shown in Figure 1, all ten male names (Valdis, Guntis, Dainis, Vilnis, Agris, Dzintars, Modris, Viesturs, Laimonis and Ziedonis) have been among the 100 most popular names in Latvia during the last century. With some variations, we can observe that their popularity emerged during the first years of independence of Latvia, then increased around World War II, but in the late 1960s, these names began increasingly losing their popularity. However, a rather noticeable fact is that in 1995, when Dainis, Agris, Valdis and Viesturs fell out of the top 100, it is only twenty years later, in 2015, that one of them, Viesturs, has reappeared. So, one would ask what happened in 1995? Did names of Latvian origin not matter anymore after the reestablishment of the independence, since there was no necessity for resistance? Or was it a different form of resistance? During the political and economic transition in the 1990's many Latvian inhabitants lived through troubled times in contrast to the emotional uplift during the so-called Third National Awakening period between 1987 and 1991. 


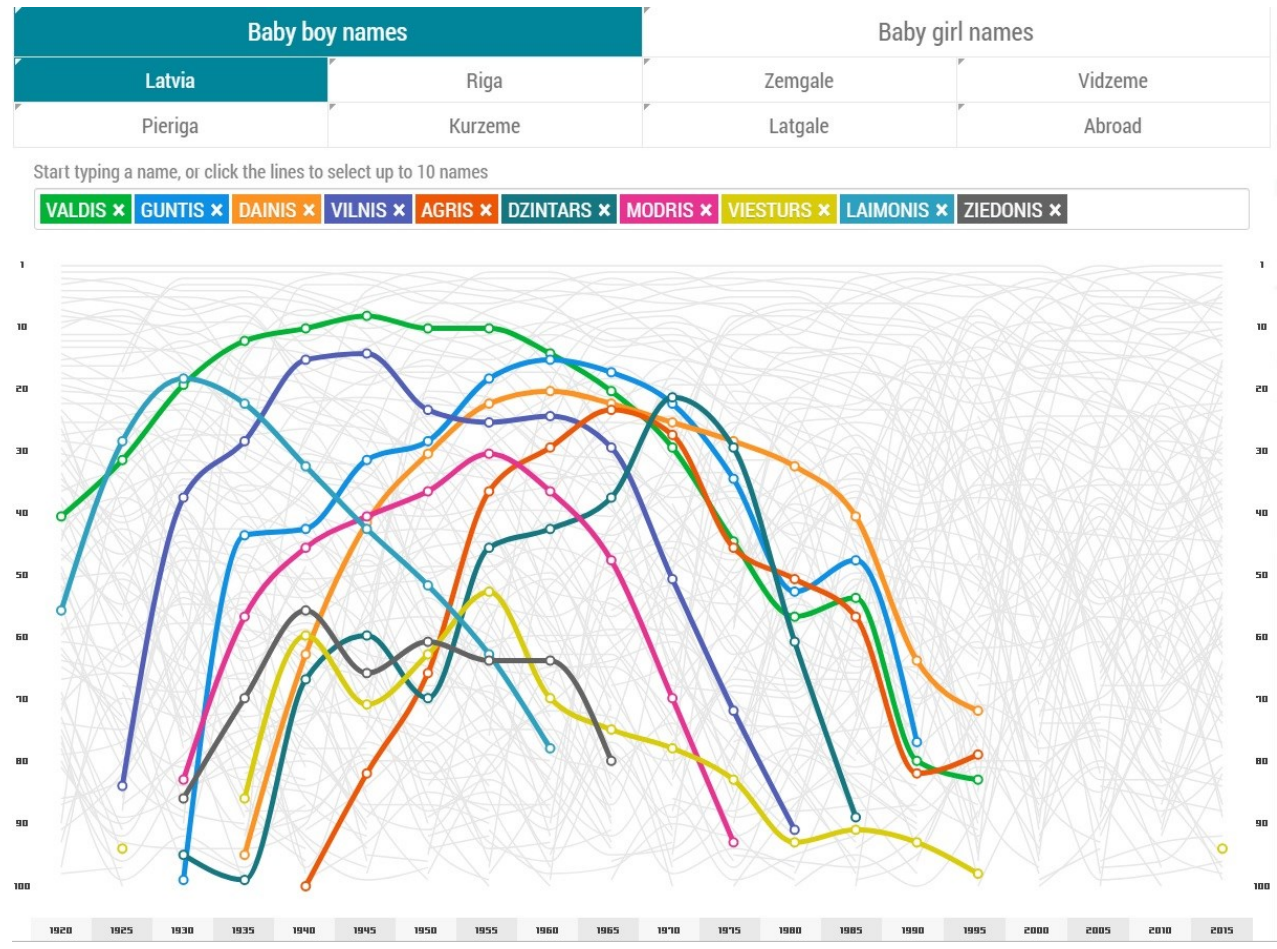

Figure 1: Popularity of ten male names of Latvian origin in respect of years in Latvia (Central Statistical Bureau of Latvia 2018).

That is to say that such a tool allows formulating some relevant questions but is rather mute when providing answers. It does not allow us to see the interactions within the process of the name giving itself, object of the present inquiry. In 2017, I conducted semi-structural interviews in Riga in order to find out what aspects does the name-giving process involve and how the personal experience as a name bearer influences the name giving. The aim of this research is to elucidate from these preliminary findings some open-ended problematics in the field of socio-onomastics in contemporary Latvia. Firstly, I present the main readings that allowed me to approach anthroponomy from an anthropological perspective. Secondly, I summarize the findings of Latvian socio-onomasticians. And lastly, I cover the results of the interviews and put them in a wider context of name giving.

\section{Linguistic and social aspects of a personal name}

\subsection{Some observations from anthropology}

The choice of a personal name should be seen as an on-going process that is linked within a triangulation: the relations between a person and its name, thus personhood, the use of the name in a wider social context like naming, as well as its meaning both on linguistic and social levels. 
What linguistic meanings does a personal name have? Bodenhorn \& vom Bruck (2006: 8) quote Mill (1947: 979-981) ${ }^{1}$ who writes that "the only names of substance which connote nothing are proper names, [...] names "ticket" people, but reveal nothing of the personality behind the mask". In this sense, the given name lacks any linguistic link with the signified - the personhood of the human being. But is it always so? Upon investigating whether names denote and words connote, Caroline Humphrey (2006: 162) discovers that for instance in Mongolia, where each personal name should be unique, common nouns as names (e.g. Tractor, Frog, etc.) are widely accepted, names are "both highly denotative and highly connotative". It is to say that personal names have the linguistic function of identification; however, the linkage between a personal name and its bearer might go beyond the purely rational.

So, what functions does a proper name have? If one of the personal name's functions is its distinctive element, then Christian Bromberger (1982) reveals its paradox since in such societies as Europe there is a highly restricted number of choices, therefore the proper name has less of a unique identification function but more so a classifying nature. Moreover, "European names, among others, can provide information about gender, kinship, class, marriage, ethnicity, and religion, reflecting existing classificatory groups" (Bodenhorn \& vom Bruck 2006: 9). Personal names are denotative to both sides as for those who have given the name and as for those who become its bearers.

How does the classification take place? In the article by Bodenhorn \& vom Bruck (2006: 10), Lévi-Strauss (1966: 166) ${ }^{2}$ is quoted as following: "one therefore never names: one classes someone else [...] one classes oneself $[\ldots]$. And most commonly one does both." Humphrey (2006: 158) suggests that "conferring a name (on someone or something) is a performative act that involves a subject-constituting power and takes place within a wider field of conventions and ideological relations". How does this performative act happen on an individual level? How does the naming take place and what does the process reveal?

\subsection{Some observations from Latvian onomasticians}

Latvian onomasticians are foremost bearers of the local understanding of personal names. Ārija Iklāva \& Dite Liepa (1999: 178) write that "personal name's research, creative findings and name day celebrations have become a national obsession". Ernests Blese, one of the first Latvian

The original reference: Mill, J. S. 1974 [1843]. A system of logic, volume 7. Ramobsen, ed. London: Longmans.

2 The original reference: Lévi-Strauss, Claude. 1966. The savage mind. London: Weidenfeld and Nicolson.

3 Quotes from articles and interviews' transcripts are translated from Latvian to English by the author. 
onomasticians to study anthroponyms, goes even further emphasizing the importance of a personal name in one's personhood: "While the name of the person is alive, the person itself is alive, and only when the name comes to an end, the person reaches its final end, too" (Blese 1929: 4). Historically, personal names in Latvia were of much broader use, such as annual time referencing and different celebrations. It might have occurred that the date of birth was not known, so people said - "he was born around Andreji" (Baltiňš 2016: 166). Most Latvian personal names are of foreign origin, namely, Hebrew, Latin, Greek, German (Bušs 1999: 412), some are influenced by the neighboring Baltic, Scandinavian and Slavonic areas. However, there is a clear understanding of Latvian names of foreign origin that are perceived as local (Hirša 2004: 411), for instance Juris that is derived from the Greek Georgus. It is also due to the fact that during the 12th and 13th centuries, Christianization had a great impact upon personal names (Silina-Pinke 2004: 436) in order to accelerate the imposed changes in the society.

Up to the present day, the main personal name source in Latvia remains the Dictionary of Latvian personal names (1990) by Klāvs Silinšs. In its introduction, Aina Blinkena (1990) decrypts the historic steps that have influenced personal names in Latvia, such as the presence of different Christian denominations or different political powers that have ruled in the current territory of Latvia. As for main motivations for the choice of given names, Blinkena (1990: 22) points out tradition, ethnic belonging, religion, family customs, political impact, literature, euphony, environment, originality, uniqueness and fashion. It is said that female personal names are more numerous and their tendencies of popularity are more dynamic (Bušs 2004: 419). There are some local beliefs, for instance, that a male name should bear an "r" to strengthen the person (Hirša 2004: 410), a father should name the son and a mother should name the daughter, or that the name day should be after the birthday (Štrausa 2007: 127). Nowadays, there is an increasing popularity of two given names (Balode \& Plēsuma 2015: 225). Several students of University of Latvia have chosen to devote their bachelor's and master's theses about name giving in contemporary Latvia. Summarizing their main findings that are based on surveying schools or kindergartens, the more recurrent motivation of name giving is euphony (e.g. Horste 2008, Kalniņa 2016, Madžule 2014, Rudzīte 2012).

To resume, name giving is not only a matter of choice but should be seen in a broader social context. It is likewise a matter of self-classification and classification of a newly born person. These processes are influenced by local socio-cultural principles. Therefore, the research aims to investigate four case studies with Latvian women who had in their recent past gone through the experience of naming their children.

4 Around 30 November. 


\section{Receiving and giving a name}

\subsection{Where does your name come from?}

In 2017, I conducted four in-depth semi-structural interviews with women aged of twenty-seven, all new mothers from Riga with higher education, about their experience naming their children. During the interviews, I tried to avoid any questions that would influence their reflections; the questions were mainly open-ended and elaborated so that there would be global reflections put into the context of their own experiences. Note that for the specific purpose of my research, each informant agreed upon the use of his or her real names and the names of their children. The personal name is a subject of inquiry to one self: how did I get my name? As for my four informants, it was mainly a decision made by one of their parents approved by the other. I introduce them, namely Elinna, Anna Aja, Anete and Linda, through their version of their personal and their children's names where some similarities already can be traced.

Elinna's name was popular and modern by the time she was born and it pursued the tradition of the initial ' $\mathrm{E}$ ' in her family. Her daughter has two names, Emilija Grieta, of which one is her preference and the other is the father's. Even though they tried to avoid a popular name, after their daughter's birth they found out that these particular names are indeed getting more and more acclaimed by parents of their generation. Anete got her name after her father's beloved fictional character. Her daughter's name Olivia was given by the child's father and she approved the choice. They have deliberately excluded the letter ' $\mathrm{j}$ ' (Olīvija is more common), so that there would be no misreading in English. Linda's mother knew since her childhood that her daughter will have such a name; moreover, it coincided euphonically with her surname. In turn, together with her husband they elaborated a list of names for boys partly based on euphony to agree on the final version, Vincents. The story of the name Anna Aja reveals a particularity about her parents' geographical origins:

I have got two names - Aja and Anna. The first one is in Arab and the second in Latvian. My parents had another alternative because they wanted to call me Umreda after my paternal grandmother, which means in Arab 'patroness of love' but they decided to reject the idea since the name in Arab cultures was out-of-date. Both my sisters have names only in Arab. [...] I don't know why they decided to name their middle child both in Arab and Latvian names. [Anna Aja]

Anna Aja's both children also have two names - Rodrigo Maliks and Amanda Jasmina. She pursued her parents' tradition in order to emphasize the double cultural heritage of the family. 


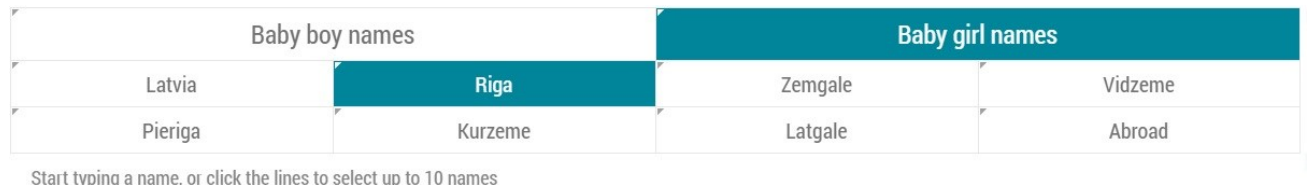

Start typing a name, or click the lines to select up to 10 names ANNA $x$ ANEIE $x$ EIINA $x$ LINDA $x$ AMANDA $x$ OLIVIJA $x$ EMILIJA $x$

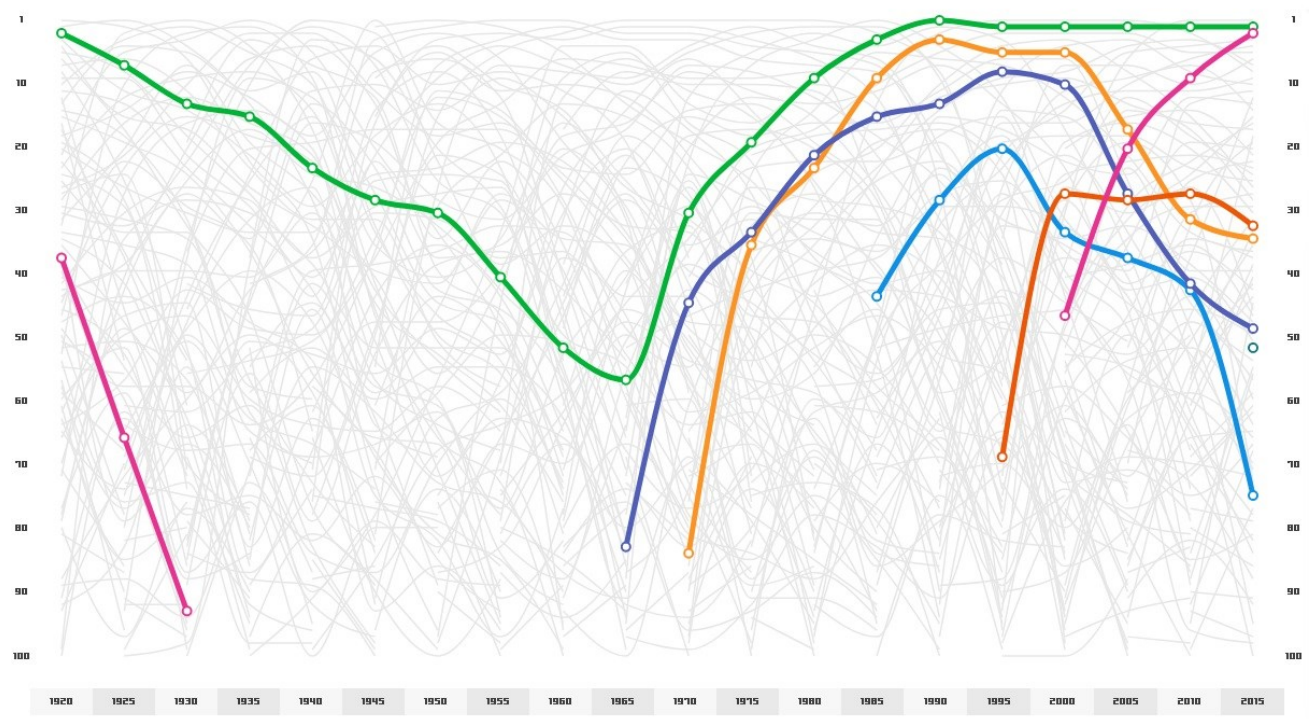

Figure 2: Popularity of informants and their children names in respect of years in Riga (Central Statistical Bureau of Latvia 2018).

Returning to the tool mentioned in the Introduction, three of my informants have received names that have gained popularity between the mid-1960s and 1980s, and, by the time they were named, around 1990s, were at the peak of their popularity. As for their children, only Vincents is not among the 100 most popular names but all girls have received at least one name that appears to become more and more popular by the time their parents were about to give them names. ${ }^{5}$ Moreover, as it is in the case of Emilija, there is a reappearance of personal names that have been popular almost a century ago. But besides being popular in a certain lapse of time, there are far more numerous aspects that have influenced their decision.

\subsection{Intersection of motivations}

\subsubsection{Tradition}

Indeed, there is an idea of a transmission of the values that one bears within their own personhood. The names are classified through their belonging to a cultural milieu. Elīna's case is illustrative, too:

5 I have adjusted the writing of Olivia to the Latvian pronunciation in order to explore its popularity. 
We wanted the name to be Latvian enough [...] after the impressions we had got about Latvian names. We did not check whether they really are [Latvian]. I really liked the name Grieta but the girl's father liked more Emillija. So, we conserved, too, the tradition of the initial "E". [Elina]

If Latvianness appears in the discourse of personal names, it is opposed to otherness. Anete finds that we are not used to non-traditional names, so when they appear, we pay more attention. A statement that coincides with Anna Aja's reflections about American names that are given to children with Latvian surnames forming hybrids such as Dženifera Bērzinga. ${ }^{6}$ Next to the borrowings that are influenced by the emigration waves to such countries as the United Kingdom, the observations about the contemporary practices go unequivocally towards a reappearance of the so-called old-school names.

I think that nowadays are characterized by the variety and the possibility of choices. For one, it is important that the name is unique, for another - a sense of belonging or a deeper significance. I think that both coexist and evolve, as it is not obvious to distinguish them. That is to say that the uniqueness can be hidden in naming someone after a grandmother, just as often Latvian given names or a name inscribed within ethnicity will also be unique, since it does not occur often that you meet a Milda or a Vizma. [Linda]

Linda's main criteria while choosing her son's name were rarity, international nature and euphony. It is the uniqueness inscribed within continuity. There is a clear idea that the combination between a human being and his name is always unique. Furthermore, unique is the possibility to offer a child a name that involves in-depth reflections about more global questions. It is a moment when such dichotomies as old-fashioned-modern, local-global or ours-foreign appear as decisive.

\subsubsection{Meaning and euphony}

Returning to the debate about connotation and denotation, it is important to note that in Latvian the grammatical gender, present also in personal names, already indicates whether the person is male or female. Nevertheless, there is a double emphasis upon the masculinity and femininity within personal names. Anna Aja knew some years before pregnancy that her future son will be named Rodrigo, a name instantaneously approved by the boy's father, since "he thought that it is very masculine and strong, because of the presence of the letter " $r$ ", or in this case even two". Elina hopes that the first name Emīlija will bring to her daughter tenderness and femininity but the second name, Grieta, strength as it bears an "r", too.

6 Dženifera or Jennifer is opposed to a clearly Latvian surname Bērziņš (diminutive of 'birch'). 
Next to gender linked issues and qualities of a child, the cultural context such as religion is also taken into account. Linda is satisfied that "my son's name, Vincents, comes from the Latin word 'conqueror', which allowed the presumption that the name will bring luck and strength. Even if we are not religious at all, I found it attractive that Vincents is a Biblical name". While the first name was not a problem for Anna Aja, she had to spend some time to find the Arab name for her son:

It had to sound well enough in Latvian, and the meaning had to be important as well. While going through boys' names in Arab, my attention was attracted by Malik, which means the Lord, and my husband was proud of it. But my father did not accept the name since in the Arab world it could be interpreted as one of the God's names, similarly as The God, and a child of man is not allowed to be named so. So, he uses his own version - Mãlik, meaning guardian angel. [Anna Aja]

The name must sound well in several senses, for instance, phonetically. There should be euphony with the surname, another factor that was taken into account by Elīna and Linda, both having their names also euphonically rethought.

The name should not bear any negative connotation in languages that are present nationally and internationally. Both Linda and Anna Aja provide examples of existing names in Latvia that are clearly provoking mockery, for example, Didars, that could be easily transformed into a swearword.

I think that one should give a name in order to allow the child to integrate himself in the cultural and the linguistic milieu of the main residence country; that it would not provoke a will to laugh at. [Linda]

However, dissatisfaction with the name can also come from other sources.

\subsubsection{Dissatisfaction}

My informants have chosen their children names together with their respective fathers and have deliberately excluded other people from this process. Nevertheless, Elīna was advised during childbirth by the midwife to leave the second name to the second child. Her grandmother who always wanted to name a child Jete went even further after discovering that her great-granddaughter was named Emïlija Grieta:

I said that my associations are that Jetes are corpulent. To what my grandmother responded that Grietas are fat and negligent but Jetes are thin as a stem of grass. [Elīna]

Anna Aja was always unsatisfied with her own name since the first name is recurrent but her second name is often confused with the Latvian Aija. Since the age of two, she called herself Annika. Regardless from her 
sympathies towards the name chosen by the child's father, Anete added a second name to her daughter, Adelina. She now regrets that, not only because the name does not correspond to the child, but also because she sees it as a "wrong implementation of her own will" as well.

Anna Aja's son, fond of the Soviet Latvian movie Emīla nedarbi ${ }^{7}$, had suggested that he would rather be called Emills. But where does the discourse of the possibility of re-naming come from?

\subsubsection{Names and nicknames}

Even if the parents more or less agree on the child's name, it is often transformed while addressing the child. First of all, there is the idea of a name for a child that is or is not yet conceived. Then the gender question comes in; my informants said that female names are considered to be an easier choice. It could also be linked with the fact that they are themselves women. Linda thinks that "girl names are more beautiful than boy names" and Elīna, a mother of a daughter, was relieved since "if it had been a boy, it would have been more difficult". If Anete did not reflect upon the name since "you have to meet the person before naming it", Anna Aja and her husband openly used the unborn child's name in front of their friends. Linda and Elinna announced the given name immediately after the birth.

But does it mean that the child will be named this way? The large number of name transformations among parents themselves and the surrounding is impressive, and sometimes leads to wonder in which frequency the given name is used. For instance, Linda calls her son by nicknames like "Vincentins, Vincis, Vinčuks, Vinčenzo, Vinčente, Cente, Vinčentanto, Vinss, Vinčs, Vinnijs". Even if the transformations are not immense, they remain transformations. Linda's and Anna Aja's mothers use consequently one concrete nickname to name their grandchildren. However, it might be a question related to the age of the child; Anete has now stopped transforming her four years-old daughter's name "in order to avoid a bad influence upon it".

After all, what is personal about name giving? The decision is important, it is discussed and overviewed in order to satisfy these circumstances that one finds important whether they are of social, linguistic or of both levels. Even if I have indicated some social characteristics regarding my informants, it is above all belonging to a generation that now lives the tendencies of their times that count. It is not the popularity or unpopularity but a sense of certain freedom of choice that unites the namegivers. However, the analysis excludes several important factors and my aim is not to generalize the name giving practices in the beginning of 21st century Latvia but to emphasize the idea that there is always an intersection of motivations when regarding the name giving itself.

7 After Astrid Lindgren's children novel's character Emil of Lönneberga. 


\section{Name day calendar and ethnic diversity}

Going through the numerous studies done by Latvian onomasticians, there is clearly only one aspect that I did not find among my informants: the name day calendar. However, all my informants as well as their children have at least one of their names in the calendar, so one could assume that it is the cultural obviousness that might explain the absence within the enumeration of motivations.

As Māris Baltinšs (2016: 165) writes in his article about the Latvian name day calendar, "there are many aspects that influence the choice of a personal name in Latvian society, such as family traditions, prestige, popular culture, trends among others but above all the presence of the name in the calendar and its emplacement within." As to him, the history of contemporary Latvian personal names is definitely a history of the Latvian name day calendar. In Latvia, name days are celebrated with nearly as much passion as birthdays. Therefore, the presence of the name in the calendar is important in order to have a celebration.

There are two versions of the name day calendar, the traditional and the expanded. Each four years the VVC (State Language Centre) Calendar Name Commission unite in order to go through the requests and, upon a certain range of criteria, decide whether to include a name in the traditional or expanded calendar or to reject the request. It is rather rare that the traditional calendar is supplemented. For instance, in 2018, only seven personal names were added. If in the traditional calendar there are only several names per day, then in the expanded their amount is rather impressive.

Table 1: Exemplification of the traditional and the expanded name day calendar in Latvia

\begin{tabular}{|c|c|c|}
\hline Date & Traditional & Supplemented \\
\hline 22 May & $\begin{array}{l}\text { Emillija. Name day of } \\
\text { all unusual names } \\
\text { and those not } \\
\text { inscribed in the } \\
\text { calendar }\end{array}$ & $\begin{array}{l}\text { Emīlija, Ahmads, Ahmeds, Airats, Ali, Alija, Džamila, } \\
\text { Emiliana, Emilija, Emilijana, Emīlja, Emiljana, Farhads, } \\
\text { Farida, Farids, Fatima, Fatina, Fatma, Gaidars, Gulnara, } \\
\text { Gul̨nara, Horens, Indira, Indīra, Ismails, Kālebs, Karima, } \\
\text { Karims, Mehribana, Murads, Muslims, Osmars }\end{array}$ \\
\hline 23 May & $\begin{array}{l}\text { Leontīne, Leokāadija, } \\
\text { Lonija, Ligija }\end{array}$ & $\begin{array}{l}\text { Leontīne, Leokādija, Lonija, Ligija, Leokadija, Leontija, } \\
\text { Leontijs, Leontina, Leontīna, Leontine, Leontins, Leontīns, } \\
\text { Levantīna, Lìgija, Ligindra, Lone, Lonita, Lonnija, } \\
\text { Lontīne, Lona }\end{array}$ \\
\hline 24 June & Jānis & Jānis \\
\hline 25 June & Milija, Maiga & $\begin{array}{l}\text { Milija, Maiga, Maida, Maigone, Mia, Mija, Milica, } \\
\text { Milita, Mille, Millija }\end{array}$ \\
\hline
\end{tabular}

To illustrate how the calendar of name days itself bears socio-cultural inscriptions, I have chosen four particular days (see Table 1). On 22 May the name day is celebrated by Emilija and all those who are not included in the calendar. However, the supplemented version has added not only some variations with the same origin as Emillija but all the names which would be more or less particular to a larger cultural milieu, namely, linked with the Islamic world. There is no similar example in the Latvian calendar and it only illustrates 
that within the increase of such demand, such classification can raise some politically marked questions. Meanwhile, there is only one personal name which is not supplemented - it is Jānis, the name that has always been among the most popular in Latvia and stands behind the festivities of summer solstice called Jāni.

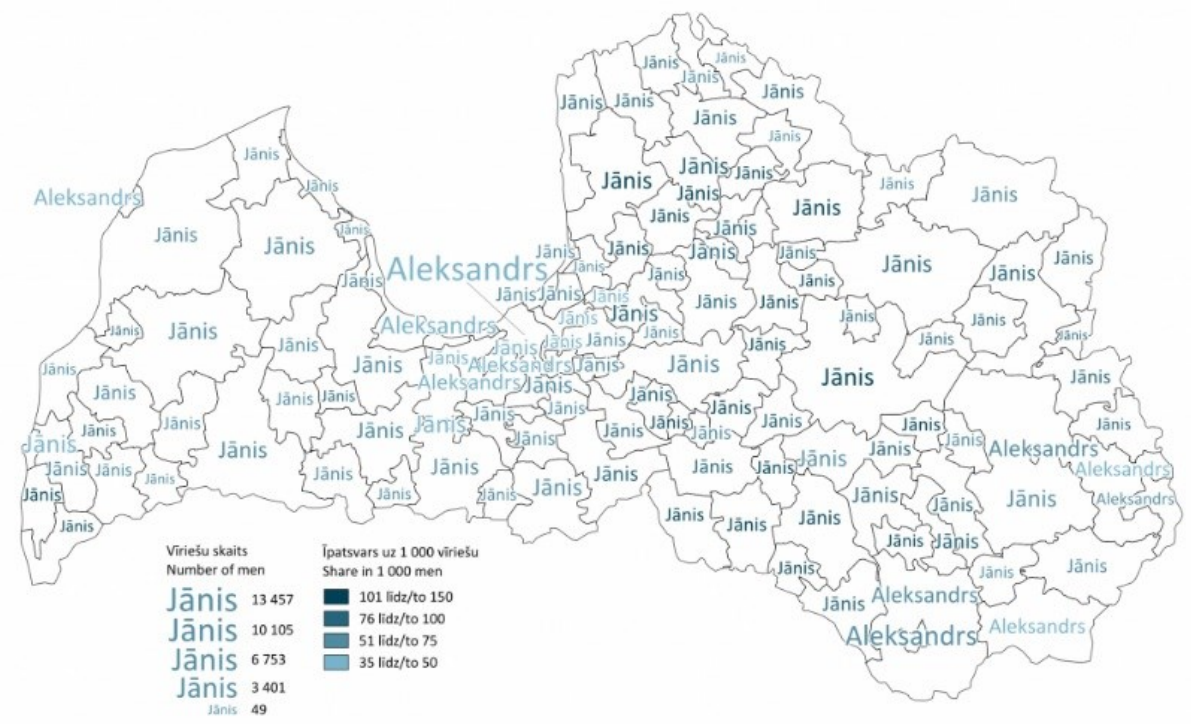

Figure 3: Most popular forenames of men at the beginning of the year 2018.

(https://www.csb.gov.lv/en/statistics/statistics-by-theme/population/characteristics/search-intheme/366-most-popular-forenames-men-beginning-year) (Accessed 2019-11-21.)

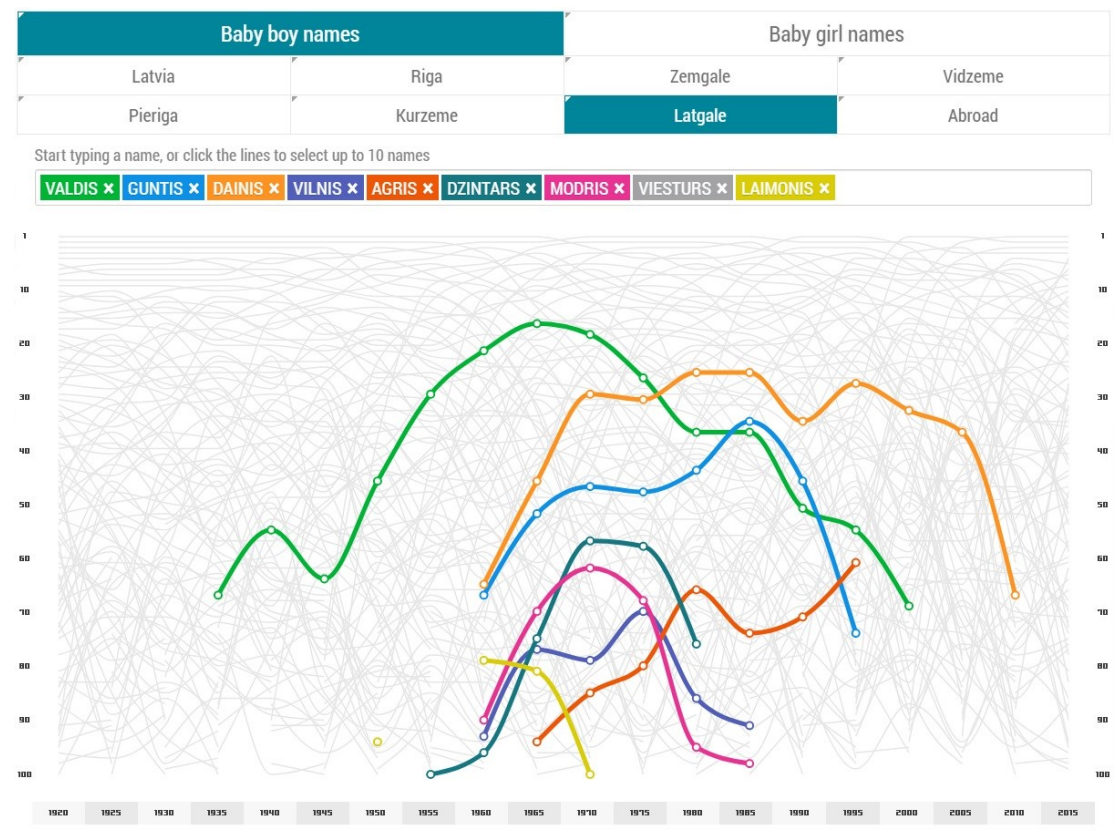

Figure 4: Popularity of ten male names of Latvian origin in respect of years in Latgale (Central Statistical Bureau of Latvia 2018). 
To emphasize the importance of the personal name Jānis, the Central Statistical Bureau has provided an interesting map (Figure 3) in the beginning of 2018 by juxtaposing the popularity of Janis and Aleksandrs. If I added a map of the ethnic diversity in Latvia, it would match more or less the relatively ethnically marked regions where Jānis would illustrate the imagined Latvianness and Aleksandrs the imagined Russianness. So, there seems to be a common thread linking Ventspils, Riga and the Latgale region which borders Russia and Belorussia.

However, the situation is not as simple as it could be by reducing Latvia into Jāni or Aleksandri. Returning to the tool I mentioned in the introduction with the example of the popularity of ten names of Latvian origin, I would like to question once again the name giving process in contemporary Latvia by the use of the same example but from a slightly different angle. By switching the four culture-historical regions and conserving the same ten names, it is indeed the Latgale region which illustratively attracts attention (see Figure 4). Instead of a clear downshift of names of Latvian origin, I can read in their statistics something else that would be worth exploring.

That is to say, above all, that the study of name-giving practices is of particular interest not only in the fact that they bear within them sociocultural inscriptions but that actually they can deliver a broader idea of sociocultural processes within a concrete society and serve as its barometer.

\section{Conclusion}

The aim of this research was to find some open-ended problematics in the field of socio-onomastics in contemporary Latvia. Anthropologists have pointed out the classificatory nature of name-giving and emphasized that it has indeed a crucial role in the personhood of a human being. The social process of naming is obviously influenced by the local socio-cultural background. In Latvia, personal names have been evolved through such historic influences as Christianization, russification policy or contemporary migration waves. The case study revealed that intersection of motivations, such as family's traditions or a personal understanding of such categories as local and global, dominate upon some rationally presentable statistics. After discovering that there is an absence of the mention of the name day calendar in the interviews, I turned the attention to it in the third part of the article. The comparison of the traditional and the expanded versions of the calendar reflects the ethnic diversity in contemporary Latvia, where there still is a tendency to reduce this subject into an opposition between Latvianness and Russianness. That is to say that giving a personal name is a sensible issue in a smaller social context but the general overview of present personal names in contemporary Latvia leads to a less stereotyped vision upon personal choices. 


\section{References}

Balode, Laimute \& Lawson, Edwin D. 1996. Latvian naming patterns, 18801991. In Proceedings of the XIXth International Congress of Onomastic Sciences Aberdeen, August 4-11, 1996, Volume 3, 244-249.

Balode, Laimute \& Plēsuma, Ieva. 2015. Retie personvārdi Latvijā trešās tūkstošgades sākumā. [Rare personal names in Latvia at the beginning of the third millennium.] Onomastica Lettica, 220-251. (4. laidiens. Atb. red. O. Bušs. Rīga: Latviešu valodas institūts.)

Baltinšs, Māris. 2016. Par personvārdiem, vārdadienām un vārdu ievietošan kalendārā [About personal names, name days and name inclusion in the calendar]. Valodas prakse: vērojumi un ieteikumi, 165-177. (Populārzinātnisks rakstu krājums. Atb. red. V. Šaudiņa. Nr. 11. Rīga: Latviešu valodas aǵentūra.)

Blese, Ernests. 1929. Latviešu personu vārdu un uzvārdu studijas I [Studies of Latvian personal names and surnames]. Rīga: A. Gulbis.

Blinkena, Aina. 1990. Ievads. In Siliņš, Klāvs (ed.), Latviešu personvārdu vārdnīca [Introduction. Dictionary of Latvian personal names]. Rīga: Zinātne.

Bodenhorn, Barbara \& vom Bruck, Gabriele. 2006. "Entangled in histories": An introduction to the anthropology of names and naming. In Bodenhorn, Barbara \& vom Bruck, Gabriele (eds.), The anthropology of names and naming, 1-29. Cambridge: Cambridge University Press.

Bromberger, Christian. 1982. Pour une analyse anthropologique des noms des personnes. Langages 66, 103-124.

Bušs, Ojārs. 1999. Dažas piezīmes par latvisko personvārdu dinamiku pēdējā pusgadsimta laikā. [Some remarks about the dynamics of personal names of Latvian origin in the last half-century.] Vārdadienu kalendārs 2000.-2003, 494-503. Rīga: Valsts Valodas Centrs.

Bušs, Ojārs. 2004. Jaunais gadu tūkstotis sākas ar revolūciju [The new millennium begins with a revolution]. Värdadienu kalendārs 20052006 2007, 417-421. Rīga: Valsts Valodas Centrs.

Central Statistical Bureau of Latvia. 2018. 100 populārākie personvārdi Latvijă kopš 1918. gada [100 most popular personal names in Latvia since 1918]. (https://vardi.csb.gov.lv/) (Accessed 2020-03-26.)

Hirša, Dzintra. 2004. Dažas pārdomas par 20. gs. populārākajiem personvārdiem [Some reflexions upon the most popular personal names in the 20th century]. Värdadienu kalendārs 20052006 2007, 409-416. Rīga: Valsts Valodas Centrs.

Horste, Evita. 2008. Jaunākās personvārdu izvēeles tendences Latvijā un Lietuva $\bar{a}$ [Latest tendencies in choosing personal names in Latvia and Lithuania]. Rīga: Latvijas Universitāte. (Master's thesis.) 
Humphrey, Caroline, 2006. On being named and not named: Authority, persons, and their names in Mongolia. In Bodenhorn, Barbara \& vom Bruck, Gabriele (eds.), The anthropology of names and naming, 158176. Cambridge: Cambridge University Press.

Iklāva, Ārija \& Liepa, Dite. 1999. Kas Daiḷprātiṇam kop̄igs ar Dārdzīti? [What Daiḷprātiņš has in common with Dārdzītis?]. Valodas prakse: vērojumi un ieteikumi, 178-191. (Populārzinātnisks rakstu krājums. Atb. red. V. Šaudina. Nr. 11. Rīga: Latviešu valodas aǵentūra.)

Kalniņa, Madara. 2016. Bērnu vārdu izvēles jaunākās tendences (balstoties uz Kauñas un Jelgavas aptaujas materiāliem) [Latest trends in choosing children names (based on survey materials in kindergartens in Kaunas and Jelgava)]. Rīga: Latvijas Universitāte. (Bachelor's thesis.)

Madžule, Madara. 2014. Bērnu vārdu izvēles motīvi (balstoties uz aptaujas datiem pirmsskolas izglìtības iestādēs) [Motives behind choosing a child's name]. Rīga: Latvijas Universitāte. (Bachelor's thesis.)

Rudzīte, Elīna. 2012. Personvārdu izvēles motīvi (Draudzīgā aicinājuma Césu valsts gimnāzijas aptaujas dati) [Motives behind choosing a personal name]. Rīga: Latvijas Universitāte. (Bachelor's thesis.)

Siliņš, Klāvs. 1990. Latviešu personvārdu vārdnīca [Dictionary of Latvian personal names]. Rīga: Zinātne.

Siliṇa-Piṇkẹe, Renāte. 2004. Viduslejasvācu valodas pēdas mūsdienu latviešu kalendārvārdos [Traces of Middle Low German language in contemporary Latvian name-day calendar]. Vārdadienu kalendārs 2005 2006 2007, 436-439. Rīga: Valsts Valodas Centrs.

Štrausa, Ilze. 2007. Par priekšvārdiem Ukru pagastā. [About personal names in Ukri parish.] Onomastica Lettica 3, 117-130. (3. laidiens. Sast. Dz. Hirša. Rīga: Latviešu valodas institūts.) 